\title{
Determination and Quantification of Gallic Acid in Raw Propolis by High-performance Liquid Chromatography- Diode Array Detector in Burundi
}

\author{
Ramadhan Nyandwi, ${ }^{a}$ Ayșe S. Kılıç, Meltem Çelik, ${ }^{b}$ Hasan H. Oruçc \\ aDoctoral School, Faculty of Medicine, University of Burundi, Bujumbura, Burundi; 'Department of Pharmacology and Toxicology, Institute of Health Sciences, Bursa \\ Uludağ University, Bursa, Turkey; 'Department of Pharmacology and Toxicology, Faculty of Veterinary Medicine, Bursa Uludağ University, Bursa, Turkey \\ Correspondence to Ramadhan Nyandwi (ramadhannyandwi@yahoo.com)
}

\begin{abstract}
Background: Honey, pollen, and propolis are among the products that bees process and derive from plants and flowers. Propolis is a resinous material that bees gather from the buds and bark of some trees and small plants. Propolis from temperate climates mainly contains phenolic compounds, in contrast with propolis from tropical climates, which mainly contains terpenes. This study aimed to determine, characterise, and quantify the phenolic content of raw propolis from Burundi.

Methods: In this study, a total of 6 samples were collected from the provinces of Rumonge, Cibitoke, and Ruyigi in Burundi. Fifteen phenolic compounds (caffeic acid, ferulic acid, epigallocatechin gallate, isoferulic acid, cinnamic acid, caffeic acid phenethyl ester, gallic acid, apigenin, chrysin, galangin, quercetin, kaempherol, rutin trihydrate, naringenin, and pinocembrin) were used as high-performance liquid chromatography (HPLC) standards for qualitative and quantitative analyses of the propolis samples.

Results: Among the 15 phenolic compounds checked, only 1 - gallic acid - was detected at a measurable level using an HPLC-diode array detector system.

Conclusion: In addition to terpenes, propolis found in sub-Saharan Africa may contain phenolic compounds. Further advanced investigation of sub-Saharan African propolis is required for more detailed characterisation.
\end{abstract}

\section{INTRODUCTION}

$\mathbf{H}$ oneybees process and produce various substances from plants and flowers, such as honey, pollen, and propolis. ${ }^{1}$ The products are components of foods and cosmetics, and they have applications in both traditional and medical practice. ${ }^{1-5}$

Propolis is a resinous material collected by honeybees from buds and cracks in the bark of certain plants, typically from poplar, beech, horse chestnut, birch and conifer trees. Bees mix this substance with beeswax and bee enzymes ( $\beta$-glycosidase) that they secrete during propolis collection. ${ }^{6-9}$ Propolis contains mainly resin and plant balsam, beeswaxes, essential oils, as well as organic and mineral compounds. ${ }^{5}$ Honeybees use propolis to plug holes, straighten inner walls, and soften the walls of their hives for protection against external invaders and hive temperature regulation. Propolis is useful for fending off potential fungal and microbial infections. $2,5,10,11$

In veterinary medicine, propolis is mostly used for its antimicrobial properties. It is also used to enhance livestock growth and productivity. ${ }^{2}$ For exam- ple, propolis has been reported to increase weight gain among chickens, subsequently improving meat quality. Propolis also increases egg laying rates among laying hens. ${ }^{9,12-14}$ Furthermore, propolis has positive effects on livestock feed consumption. ${ }^{4,14}$ It can also be used in veterinary medicine to treat canine fungal otitis and dermal mycosis infections as well as bovine dermatophytosis. ${ }^{15,16}$

Propolis is also an ingredient of cosmetic creams and lotions. It can be used in shampoos and hair lotions, acne treatments, shaving products, deodorants, antiperspirants, as well as antidandruff and sebum-stabilising agents. ${ }^{2}$ In addition to its pharmaceutical uses, propolis may be used as a food preservative, owing to its natural antioxidant and antibacterial effects. ${ }^{2,7}$

Despite its beneficial properties, propolis also has adverse effects, particularly when used by or administered to sensitive individuals and in high doses. In humans, it can cause allergic and other adverse reactions, including contact dermatitis or oral mucositis. 11,17,18 $^{2}$ 
Data about bees and bee products are available from almost every known period of human history. ${ }^{19}$ Propolis has been used by the Egyptians, Greeks, Persians, Arabs, and Romans since ancient times. Moreover, most religious books have spoken about bees and honey. ${ }^{5,20}$ Propolis has been used in traditional and modern medicine as an alternative and supportive treatment for its antibacterial, antifungal, anti-inflammatory, antiviral, antioxidant, gastroprotective, neuroprotective, anti-ulcerative, antispasmodic, chelator, immuno-modulatory, and sedative properties. It has also been used to treat and prevent acne, allergies, liver disease, diarrhoea, diabetes, pain, ageing, malaria, and heart disease. ${ }^{1,2,4,7,21-24}$

More than 300 active compounds have been identified in propolis, with the composition varying by season, plant source, bee species, and altitude. ${ }^{8}$ The most important components with pharmacological activity in propolis are flavonoids, like flavones, flavanols, flavanone, and various phenolic and aromatic substances. ${ }^{2,4,68,9,11}$ Flavonoids are not toxic when consumed in fruits and vegetables; they are potentially useful compounds for the human body and protect plants against microbial infection and insect infestation. ${ }^{22}$

Many countries have investigated the chemical composition of their indigenous propolis and identified its biopharmaceutical effects. For instance, propolis has been extensively studied in Europe and South America (especially in Brazil), and there are ongoing detailed studies in China, Japan, Taiwan, and Turkey, among other countries. ${ }^{8}$ However, studies on African propolis are few and limited to North African countries, such as Morocco, Algeria, and Egypt. ${ }^{25}$

African vegetation is suitable for beekeeping and, therefore, suitable for propolis production. However, there is a lack of data related to African propolis, and in some countries and regions, including Burundi, there is no available information about the chemical content of the local propolis. Nevertheless, research on propolis in sub-Saharan Africa has shown that, in general, African propolis - like the propolis found in other tropical regions - is rich in terpenoids, including $\alpha$-amyrine, $\beta$-amyrin, $\alpha$-amyryl acetates, $\beta$-amyryl acetates, $\mathrm{n}$-alkanes, $\mathrm{n}$-alkenes, methyl n-alkanoates, and long-chain wax esters, among other compounds. ${ }^{25-30}$

The price of propolis varies according to its source and quality. For example, Chinese propolis is offered for sale at about $€ 25$ to $€ 50$ euros per $\mathrm{kg}$, while the Brazilian propolis is offered at higher prices ( $€ 100$ to $€ 150$ euros per $\mathrm{kg}$ ). ${ }^{31}$ For this reason, propolis production can be beneficial for a nation's economy in general and particularly profitable for beekeepers. However, for this to be the case, the propolis produced must be of good quality and have the desired pharmacological effects. It is, therefore, necessary to carry out chemical analyses of total phenolic content to assess propolis quality for consumer use. This study aimed to identify, quantify, and characterise the presence of phenolic compounds in Burundian propolis.

\section{METHODS}

\section{Sample Collection}

A total of 6 propolis samples were randomly collected from 3 provinces in Burundi by placing at least 4 propolis traps in each province. First, in Rumonge Province, samples were collected from the Rumonge ( 2 samples) and Buyengero ( 2 samples) communes. Second, in Cibitoke Province, 1 sample was collected from Murwi. Finally, in Ruyigi Province, 1 sample was collected from Kinyinya. Propolis samples were collected using plastic propolis traps $(42 \times 49.5 \mathrm{~cm})$ (Civan Incorporation, Bursa, Turkey). Propolis traps were placed on the hive in place of the inner cover for a month during the spring season. Propolis samples were immediatey stored in a refrigerator before any analysis.

\section{Instruments, Chemical Reagents, and Standards}

All reagents used for this study - including methanol, acetonitrile, ethanol, and formic acid - were high-performance liquid chromatography (HPLC)-quality grade. A PURELAB flex 4 (ELGA LabWater, Buckinghamshire, UK) system was used to purify water. For quantitative analyses, we used HPLC coupled with diode array detector (DAD) (Shimadzu Corporation, LC-20 AD/SPD-M20A, Tokyo, Japan) analysis. A vacuum drier system (Jouan Inc., RC 10-10, Winchester, VA, USA) was used to concentrate propolis extracts.

The standards of phenolic compounds used in the analyses were:

1. Caffeic acid (3,4-dihydroxycinnamic acid, trans-3,4-dihydroxycinnamic acid; molecular weight: 180.16, Chemical Abstracts Service [CAS] number: 331-39-5; Sigma-Aldrich, C0625, $\geq 98 \%$ )

2. Epigallocatechin gallate ((-) -cis-2-(3,4,5-trihydroxyphenyl)-3,4-dihydro-1 (2H)-benzopyran-3,5,7-triol 3-gallate, (-) -cis-3,3 EG, 4-, 5,5 fla, 7-hexahydroxy-flavane-3-gallate, EGCG, Teavigo; molecular weight: 458.37, CAS number: 989-51-5; Santa Cruz, sc-200802, $\geq 98 \%$ )

3. Trans-isoferulic acid (trans-3-(3-hydroxy4-methoxyphenyl) acrylic acid, trans-3-hydroxy-4-methoxycinnamic acid; molecular weight: 194.1, CAS number: 25522-33-2; Fluka, 05407, $\geq 98 \%$.

4. Ferulic acid (3-hydroxy-4-methoxycinnamic acid, caffeic acid 3-methyl ether, coniferic acid; molecular weight: 194.18, CAS number: 537-984; Fluka, 52229, 99\%)

5. Trans-cinnamic acid (trans-3-phenylacrylic acid, trans-cinnamate, trans-3-phenylacrylate; molecular weight: 148.16, CAS number: 140-103, Sigma-Aldrich, C80857, $\geq 99 \%$ ) 
6. Caffeic acid phenetyl ester (CAPE) (2-phenylethyl caffeate; molecular weight: 284.31, CAS number: 104594-70-9; Sigma-Aldrich, C8221, >97\% )

7. Gallic acid (3,4,5-trihydroxybenzoic acid; molecular weight: 170.12, CAS number: 149-91-7, Sigma-Aldrich, G7384, $\geq 97.5 \%$ )

8. Apigenin (4 in, 5,7-trihydroxyflavone, naringenin chalcone; molecular weight: 270.24 , CAS

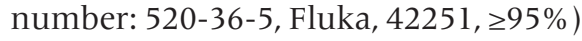

9. Chrysin (5,7-dihydroxyflavone; molecular weight: 254,24, CAS number: 480-40-0; Sigma-Aldrich, C80105, 97\%)

10. Galangin (3,5,7-trihydroxyflavone; molecular weight: 270.24, CAS number: 548-83-4, Sigma-Aldrich, 282200, 95\% )

11. Quercetin hydrate (3,3,'4',5,7-pentahydroxyflavone; molecular weight: 302.24, CAS number:

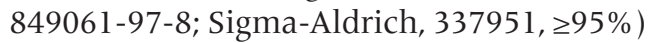

12. Kaempherol (3,4 35, 5,7-tetrahydroxyflavone; molecular weight: 286.24, CAS number: 520-183, Fluka, 96353, $\geq 99 \%$ )

13. Rutin trihydrate (quercetin-3-rutinoside trihydrate, vitamin P trihydrate; molecular weight: 664.56, CAS number: 250249-75-3; Fluka, 78095, $\geq 95 \%$ )

14. Naringenin (4,5,7-trihydroxyflavanone; molecular weight: 272.25, CAS number: 67604-48-2; Fluka, 52186, $\geq 95 \%$ )

15. Pinocembrin (S-5,7-dihydroxyflavanone, dihydrochrysin, galangin flavanone; molecular weight: 256.25, CAS number: 480-39-7; Fluka, P5239, $\geq 95 \%$ )

\section{Analysis}

During analysis, 70\% (V/V) ethanol was used as a solvent. Phenolic compound standards were dissolved in methanol to prepare stock solutions at $1 \mu \mathrm{g} / \mathrm{ml}$. Each phenolic compound standard was injected individually into the HPLC system to determine its main peak, time of arrival, and spectrum. Next, mixed phenolic solutions were prepared by mixing the final concentrations of the phenolic compound solutions to a concentration of $48 \mu \mathrm{g} / \mathrm{ml}$. The mixed phenolic solutions were diluted with methanol to form calibration curves, and 5 different intermediate solutions were prepared at concentrations of $3,6,12,24$, and $48 \mu \mathrm{g} / \mathrm{ml}$. The correlation coefficients $\left(\mathrm{R}^{2}\right)$ of the calibration curves varied between 0.967 and 0.999 depending on the phenolic composition. The limit of quantification values of the phenolic compounds ranged from 2.46 to $7.56 \mu \mathrm{g} / \mathrm{ml}$, and the limit of detection values varied from 0.82 to $3.36 \mu \mathrm{g} / \mathrm{ml}$.

\section{TABLE 1. Mobile Phase Flowchart}

\begin{tabular}{lcc}
\hline Time, min & $\begin{array}{c}\text { Mobile Phase } \\
\text { A, \% }\end{array}$ & $\begin{array}{c}\text { Mobile Phase } \\
\text { B, \% }\end{array}$ \\
\hline 0.01 & \multicolumn{2}{c}{ Start } \\
0.02 & 90 & 10 \\
3 & 75 & 25 \\
15 & 70 & 30 \\
60 & 50 & 50 \\
70 & 40 & 60 \\
80 & 10 & 90 \\
85 & 40 & 60 \\
90 & 75 & 25 \\
95 & 90 & 10 \\
104 & & \\
& &
\end{tabular}

\section{Sample Extraction and Analysis}

Propolis extraction was done at a dilution rate of 1:9, mainly using the extraction method described by Oruç et al. ${ }^{8}$ Raw propolis samples were frozen at $-20^{\circ} \mathrm{C}$ for 30 minutes, then ground into powder using a De'Longhi KG49 electric coffee grinder (De'Longhi, Treviso, Italy). Powdered propolis samples were thoroughly mixed, and $2 \mathrm{~g}$ of each sample was weighed for extraction. Then, $18 \mathrm{ml}$ of $70 \%$ ethanol was added to obtain a propolis-ethanol extract (PEE). This mixture was first stirred with an orbital shaker (SL-350, Nüve, Ankara, Turkey) for 1 hour, followed by ultrasonication in an ultrasonic bath (Sonorex RK100, Bandelin, Berlin, Germany) for 15 minutes. This process was carried out twice. The mixture was then filtered, first using grade 1 rectangular filter paper and then grade 1 Whatman filter paper (125 mm). The obtained PEE was preliminarily collected in weighed empty tubes and then concentrated using a vacuum drier. After drying the PEE, the tubes were weighed again, and the dry weights were calculated. The amount of dry PEE per tube was recorded, and the tubes were stored at $-20^{\circ} \mathrm{C}$ until the HPLCDAD analysis stage. The dry PEE was solved with methanol ( $1: 10, w: v)$ and filtered through a polyvinyl difluoride syringe filter (Millipore Millex-HV, $0.45 \mu \mathrm{m}$ ), and $5 \mu \mathrm{l}$ injected into the HPLC-DAD system.

We mainly used the methods described by Pellati et $\mathrm{al}^{32}$ for HPLC-DAD analysis. The PEE samples were prepared in tubes and filtered again through $0.45 \mu \mathrm{m}$ polyvinyl difluoride (Millipore Millex-HV, $0.45 \mu \mathrm{m}$ ), and $5 \mu \mathrm{l}$ of the obtained solu- 
TABLE 2. Characteristics of Collected Samples

\begin{tabular}{|c|c|c|c|c|c|c|c|c|}
\hline \multirow{2}{*}{ Location } & \multicolumn{3}{|c|}{ Color } & \multirow{2}{*}{ Sticky Consistency } & \multicolumn{3}{|c|}{ Aromatic Scent } & \multirow{2}{*}{ Weight, $g$} \\
\hline & Red & Black & Brown & & Strong & Weak & Very Weak & \\
\hline Rumonge 1 & & & Yes & Yes & & Yes & & 56 \\
\hline Rumonge 2 & & Yes & & Yes & & Yes & & 87 \\
\hline Buyengero 1 & Yes & & & Yes & & Yes & & 64 \\
\hline Buyengero 2 & Yes & & & Yes & & Yes & & 98 \\
\hline Murwi & & & Yes & Yes & & & Yes & 86 \\
\hline Kinyinya & & Yes & & Yes & & Yes & & 128 \\
\hline
\end{tabular}

TABLE 3. Burundian Propolis Component Concentrations

\begin{tabular}{|c|c|c|c|c|c|c|}
\hline \multirow{2}{*}{ Compound } & \multicolumn{6}{|c|}{$\begin{array}{l}\text { Concentration, } \mu g / g \text {, } \\
\text { According to Geographic Origin }\end{array}$} \\
\hline & Rumonge 1 & Rumonge 2 & Buyengero 1 & Buyengero 2 & Murwi & Kinyinya \\
\hline GAL & 33 & 832 & 163 & 31 & - & 22 \\
\hline EGKG & - & - & - & - & - & - \\
\hline $\mathrm{KA}$ & - & - & - & - & - & - \\
\hline FR & - & - & - & - & - & - \\
\hline IFR & - & - & - & - & - & - \\
\hline QE & - & - & - & - & - & - \\
\hline SA & - & - & - & - & - & - \\
\hline NR & - & - & - & - & - & - \\
\hline$A P$ & - & - & - & - & - & - \\
\hline KF & - & - & - & - & - & - \\
\hline$C R$ & - & - & - & - & - & - \\
\hline $\mathrm{PN}$ & - & - & - & - & - & - \\
\hline $\mathrm{GL}$ & - & - & - & - & - & - \\
\hline CAPE & - & - & - & - & - & - \\
\hline RT & - & - & - & - & - & - \\
\hline
\end{tabular}

Abbreviation: GAL, gallic acid; EGGG, epigallocatechin gallate; KA, caffeic acid; FR, trans-ferulic acid; IFR, isoferulic acid; QE, quercetin; SA, cinnamic acid; NR, naringenin; AP, apigenin; KF, kaempherol; CR, chrycin; PN, pinocembrin; GL, galangin; CAPE, caffeic acid phenethyl ester; RT, rutin trihydrate 
tion was injected into the HPLC-DAD system automatically. The method is gradient where mobile phase A (deionised water plus $0.1 \%$ formic acid, V/V) and mobile phase B (HPLC grade acetonitrile plus $0.1 \%$ formic acid, V/V) were used as solvent carriers (Table 1). The mobile phase's total flow rate was $1 \mathrm{ml} / \mathrm{min}$ between 80 and 90 bar of pressure on the pump with a total injection volume of $5 \mu \mathrm{l}$ at temperatures between $25^{\circ} \mathrm{C}$ and $33^{\circ} \mathrm{C}$. During the analyses, the column temperature was kept at $30^{\circ} \mathrm{C}$. Detection of the propolis content was carried out at a wavelength of $270 \mathrm{~nm}$, and the compounds were obtained by identification and comparison of retention time values and peaks of samples and standards.

The propolis extraction and HPLC-DAD analysis procedures were carried out at Uludag University's Department of Pharmacology and Toxicology within the Faculty of Veterinary Medicine, in Bursa, Turkey. The phenolic compound concentrations in the dry PEEs were calculated in $\mu \mathrm{g} / \mathrm{g}$.

\section{RESULTS AND DISCUSSION}

Analysed propolis samples were sticky, red, black, and brown with a slight aromatic smell (Table 2). There were also differences between the participating communes in terms of the propolis sample volumes collected, and, overall, the volume of propolis samples collected was small (Table 3). During collection, propolis was generally found in the edge sections of the traps used for harvesting, with the middle sections being empty or slightly waxy. Propolis is typically described as having a fibrous, matte, sticky, and bright appearance, with colours ranging from red, yellow, and green to dark brown depending on the plant source and region; our propolis samples matched these characteristic descriptions. Many researchers have also described the aromatic scent of propolis. ${ }^{2,5,8,20,33-37}$

Among all of the samples collected, only gallic acid was determined at a measurable level. The mean gallic acid concentration was $216.2 \mu \mathrm{g} / \mathrm{g}$ (Table 3), which is low compared to propolis found in temperate regions. In this study, according to the method used, chromatogram peaks were weak, small, and low in number and mainly appeared from 1 minute up to 15 minutes. This finding is in contrast to observations reported by Oruç et $\mathrm{al}^{8}$, who - using the same methods as we did - investigated propolis samples from the temperate climate of Turkey and found that peaks were consistent, high, and numerous; their chromatogram peaks appeared between 1 minute and 70 minutes.

Gallic acid is a phenolic compound with antibacterial ${ }^{38}$ and antitumour ${ }^{39}$ activity. The constituent phenolic compounds found in Burundian propolis are quantitatively and qualitatively different from the propolis components found in temperate climates. Previous studies conducted in sub-Saharan Africa have revealed propolis from this region to contain a high terpenoid content. ${ }^{26,30}$ This has been confirmed by researchers, such as Zhang et al, ${ }^{30}$ who investigated propolis samples from Uganda, Tanzania, Malawi, Zambia, South Africa, Cameroon, Nigeria, and The Gambia. They concluded that African propolis was rich in diterpenoids and triterpenoids.
Papakroni et $\mathrm{al}^{26}$ found, for the first time, triterpenes, such as lupennon, $\beta$-amirin and lupeol, diprenyl-flavonoid lonchocarpol, and 6,8-diprenyl-eriodictyol in propolis samples from the Democratic Republic of Congo. Rushdi et $\mathrm{al}^{27}$ found $\alpha$-amyrin, $\beta$-amyrin, $\alpha$-amyryl acetates, $\beta$-amyryl acetates, n-alkanes, n-alkenes, methyl n-alkanoates, and long-chain wax esters in propolis samples from Ethiopia.

\section{CONCLUSION}

The absence of phenolic compounds other than gallic acid in Burundian propolis samples from is in concordance with studies that have reported terpenoids as the main constituents of propolis found in tropical areas, including sub-Sahara Africa. Despite the limitations of our study - including the small number of samples and narrow geographical distribution of propolis - the detection of gallic acid is important in terms of propolis quality and consumption and can be looked at as a starting point for designing new methods for characterising and quantifying the phenolic content of propolis from sub-Saharan Africa.

Acknowledgements: The project was supported by The Commission of Scientific Research Project of Uludag University (Project No: HDP (V)-2017-25). We are grateful Uludag University for providing laboratory and logistical support. We also acknowledge the support of Prof. Songül Sonal, Prof. Murat Cengiz, and Meltem Çaycı.

\section{REFERENCES}

1. Doğaroğlu M. Arı ürünleri ve sağlık. In: Akçiçek E, Yücel B, eds. Arı Ürünleri ve Sağlık (Apiterapi). 1st ed. Izmir, Turkey: Sida Medya; 2015. p. 17-23. Turkish.

2. Krell R. Value Added Product from Beekeeping. FAO Agricultural Services Bulleting No. 124. Rome, Italy: Food and Agriculture Organization of the United Nations; 1996. http://www.fao.org/3/w0076e/w0076e00.htm. Accessed 13 March 2019.

3. Gökçe EH, Özer Ö. Kozmeotolojide arı ürünlerimin kullanımı. In: Akçiçek E, Yücel B, eds. Arı Ürünleri ve Sağlık (Apiterapi). 1st ed. Izmir, Turkey: Sida Medya; 2015. p. 197-202. Turkish.

4. Oruç HH, Sorucu A, Aydın L. Propolisin sağlık açısından önemi, kalitesinin belirlenmesi ve Türkiye açısından irdelenmesi. Uludağ Arıcılık Dergisi [Uludağ Bee J]. 2014;14(1):35-43. Turkish.

5. Kuropatnicki A, Szliszka E, Krol W. Historical aspect of propolis research in modern times. Evid Based Complement Alternat Med. 2013;2013:964149. CrossRef. Medline

6. Kumova U, Korkmaz A, Avci BC, Ceyran G. Önemli bir arı ürünü: propolis. Uludağ Arıcılık Dergisi [Uludağ Bee J]. 2002;2(2):10-23. Turkish.

7. Mohdaly AAA, Mahmoud AA, Roby MHH, Smetanska I, Ramadan MF. Phenolic extract from propolis and bee pollen: composition, antioxidant and antibacterial activities. J Food Biochem. 2015;39(5):538-547. CrossRef

8. Oruç HH, Sorucu A, Ünal HH, Aydin L. Effects of season and altitude on biological active certain phenolic compounds levels and partial standardization of propolis. Ankara Üniv Vet Fak Derg. 2017;64:13-20. Turkish.

9. Seven I, AKSU T, Seven PT. Propolis ve hayvan beslemede kullanımı. Yüzüncü Yıl Üniv Vet Fak Derg. 2007;18(2):79-84. Turkish.

10. Bulut $S$, Lenger DS. Antik dönemde arı ürünlerinin kullanımı. In: Akçiçek $E$, Yücel B, eds. Arı Ürünleri ve Sağlık (Apiterapi). 1st ed. Izmir, Turkey: Sida Mediya; 2015. p. 7-16. Turkish.

11. Miguel MG. Chemical and biological properties of propolis from the western countries of the Mediterranean Basin and Portugal. Int J Pharm Pharmaceut Sci. 2013;5(3):403-409.

12. Abdel-Kareem AAA, El-Sheikh TM. Impact of supplementing diets with propolis on productive performance, egg quality traits and some haematological variables of laying hens. J Anim Physiol Anim Nutr (Berl). 2017;101(3):441-448. CrossRef. Medline 
13. Mahmoud UT, Cheng HW, Applegate TJ. Functions of propolis as a natural feed additive in poultry. World Poult Sci J. 2016;72(1):37-48. CrossRef

14. Șahin A, Baylan M, Șahinler N, Canoğullari S, Gül A. Propolisin Japon bıldırcınlarından besi performansı ve etkisi. Uludağ Arıılık Dergisi [Uludağ Bee J]. 2003;3(4):42-44. Turkish.

15. Cam Y, Koc AN, Silici S, et al. Treatment of dermatophytosis in young cattle with propolis and Whiffield's ointment. Vet Rec. 2009;165(2):57-58. CrossRef. Medline

16. Lozina LA, Peichoto ME, Boehringer SI, Koscinczuk P, Granero GE, Acosta OC. Efficacy of Argentine propolis formulation for topical treatment of canine otitis externa. Arq Bras Med Vet Zootec. 2010;62(6):1359-1366. CrossRef

17. Banskota AH, Tezuka Y, Kadota S. Recent progress in pharmacological research of propolis. Phytother Res. 2001;15(7):561-571. CrossRef. Medline

18. Burdock GA. Review of the biological properties and toxicity of bee propolis (propolis). Food Chem Toxicol. 1998;36(4):347-363. CrossRef. Medline

19. Doğanay A, Aydın L, Girișgin AO, Güneș ME. Genel aricilik. In: Doğanay A, Aydın L, eds. Bal Arısı Yetiștiriciliği Ürünleri Hastalıkları. 1st ed. Bursa, Turkey: Dora Basım-Yayın Dağııım; 2017.

20. Oruç HH, Güneș ME, Aydın L, Girișgin AO. Arı Ürünleri, Arı sokmasi ve veteriner apiterapi. In: Doğanay A, Aydın L, eds. Bal Arısı Yetiștiriciliği Ürünleri Hastalıkları. 1st ed. Bursa, Turkey: Dora Basım-Yayın Dağıım; 2017.

21. Cardinault N, Cayeux MO, Percie Du Sert P. La propolis: origine, composition et propriétés. Phytothér. 2012;10(5):298-304. French. CrossRef.

22. Osés SM, Pascual-Maté A, Fernández-Muiño MA, López-Díaz TM, Sancho MT. Bioactive properties of honey with propolis. Food Chem. 2016;19691):12151223. CrossRef

23. Popova MP, Bankova VS, Bogdanov S, et al. Chemical characteristics of poplar type propolis of different geographic origin. Apidologie. 2007;38(3):306311. CrossRef

24. Popova M, Dimitrova R, Al-Lawati HT, Tsvetkova I, Najdenski H, Bankova V. Omani propolis: chemical profiling, antibacterial activity and new propolis plant sources. Chem Cent J. 2013;7:158. CrossRef. Medline

25. Petrova A, Popova M, Kuzmanova C, et al. New biologically active compounds from Kenyan propolis. Fitoterapia. 2010;81(6):509-514. CrossRef. Medline

26. Papachroni D, Graikou K, Kosalec I, Damianakos H, Ingram V, Chinou I. Phytochemical analysis and biological evaluation of selected African propolis samples from Cameroon and Congo. Nat Prod Commun. 2015;10(1):67-70. Medline

27. Rushdi AL, Adgaba N, Bayaqoob NIM, et al. Characteristic and chemical composition of propolis from Ethiopia. Springerplus. 2014;3:253. CrossRef. Medline

28. Suleman T, van Vuuren $S$, Sandasi M, Viljoen AM. Antimicrobial activity and chemometric modelling of South African propolis. J Appl Microbiol. 2015;119(4):981-990. CrossRef. Medline

29. Ukulo JW, Kiiyukia C, Kenji GM. Antioxidative and radical scavenging activities of propolis extracts in food models. Afr J Food Agric Nutr Dev. 2013;13(1):7273-7287.
30. Zhang T, Omar R, Siheri W, et al. Chromatographic analysis with different detectors in the chemical characterization and dereplication of African propolis. Talanta. 2014;120:181-190. CrossRef. Medline

31. Bogdanov S, Bankova V. Propolis: origin, production, composition. In: Bogdanov S, ed. The Propolis Book. Muehlethurnen, Switzerland: Bee Hexagon Knowledge Network; 2017. http://www.bee-hexagon.net/propolis/. Accessed 13 March 2019.

32. Pellati F, Orlandini G, Pinetti D, Benvenuti S. HPLC-DAD and HPLC-ESI-MS/MS methods for metabolite profiling of propolis extracts. J Pharm Biomed Anal. 2011:55(5):934-948. CrossRef. Medline

33. Bankova V, Popova M, Trusheva B. Plant sources of propolis: an update from a chemist's point of view. Nat Prod Commun. 2006;1:1023-1028. CrossRef

34. Bankova V, Popova M, Trusheva B. Propolis volatile compounds: chemical diversity and biological activity: a review. Chem Cent J. 2014;8:28. CrossRef. Medline

35. Bankova V, Trusheva B. Chemical profiles of different propolis types in relation to their biological activity. In: Farooki T, Farooki A, eds. Beneficial Effects of Propolis on Human Health and Chronic Diseases. New York: Nova Sciences Publishers; 2013. p. 166-203.

36. Cirasino L, Pisati A, Fasani F. Contact dermatitis from propolis. Contact Dermatitis. 1987;16(2):110-111. CrossRef. Medline

37. Wagh VD. Propolis: a wonder bees product and its pharmacological potentials. Adv Pharm Sci. 2013;2013:308249. CrossRef. Medline

38. Alday E, Navarro-Navarro M, Garibay-Escobar A, Robles-Zepeda R, Hernandez J, Velazquez C. Advances in pharmacological activities and chemical composition of propolis produced in Americas. In: Chambo ED, ed. Beekeeping and Bee Conservation - Advances in Research. London: InTechOpen; 2016. https://www.intechopen.com/books/beekeeping-and-bee-conservation-advances-in-research/advances-in-pharmacological-activities-and-chemical-composition-of-propolis-produced-in-americas. Accessed 13 March 2019.

39. Raina K, Rajamanickam S, Deep G, Singh M, Agarwal R, Agarwal C. Chemopreventive effects of oral gallic acid feeding on tumor growth and progression in TRAMP mice. Mol Cancer Ther. 2008;7(5):1258-1267. CrossRef. Medline

\section{Peer Reviewed}

Competing Interests: None decleared.

Received: 7 Sep 2018; Accepted: 3 Mar 2019

Cite this article as: Nyandwi R, Kıllıç AS, Celik M, Oruçc HH. Determination and Quantification of Gallic Acid in Raw Propolis by High-performance Liquid Chromatography-Diode Array Detector in Burundi. E Afr Sci. 2019;1 (1):43-48. https:// doi.org/10.24248/EASci-D-18-00004.

(c) Nyandwi et al. This is an open-access article distributed under the terms of the Creative Commons Attribution License, which permits unrestricted use, distribution, and reproduction in any medium, provided the original author and source are properly cited. To view a copy of the license, visit http://creativecommons.org/licenses/by/4.0/. When linking to this article, please use the following permanent link: http://doi.org/10.24248/EASci-D-18-00004. 